\title{
General Confiscation Versus Criminal Confiscation in Regard to Curators' Authority and Responsibility in Bankruptcy Settlement Process
}

\author{
Elli Ruslina*, Siti Rodiah and Benny Wulur \\ Faculty of Law, Universitas Pasundan, Bandung, Indonesia \\ *elli.ruslina@unpas.ac.id
}

Published: 15/08/2020

\begin{abstract}
How to cite:
Ruslina, E., Rodiah, S., Wulur, B. 2020. General Confiscation Versus Criminal Confiscation in Regard to Curators' Authority and Responsibility in Bankruptcy Settlement Process. Sociological Jurisprudence Journal. Volume 3 Issue 2. Page 112 - 116. https://doi.org/10.22225/ scj.3.2.1803.112-116
\end{abstract}

\begin{abstract}
The process of bankruptcy general confiscation sometimes clashes with criminal confiscation process. The present study aims to look at curators' authority and responsibility to sell bankrupt properties, which have been confiscated by investigating officers in a case of criminal confiscation. It also delves into the legal ramifications that may occur and into the concepts of bankruptcy settlement. This study employs a juridical normative method and the necessary legal material are collected through literature study. The legal material are analyzed in juridical qualitative approach, using a comparison between bankruptcy laws in several countries. Based on the result of this study, it is concluded that curators' authority and responsibility are still applicable even though they are subject to appeal. The legal consequences in the case that bankrupt estate is being confiscated by investigating officers due to the conflict between criminal confiscation and general confiscation require the court to prioritize the criminal confiscation. Once it is resolved, bankruptcy assets/estate are returned to the curator. This study recommends that there should be an effort to legally synchronize and harmonize Article 39 Point (2) of KUHAP (Indonesian Law of Criminal Procedure) with Article 31 Point (2) of Law No. 37 Year 2004 Concerning Bankruptcy and PKPU (Suspension of Payment/Debt Moratorium). One of the solutions offered in this study is by implementing E-Court, as is the case in Indonesia's Constitutional Court, especially in Commercial Court whose habitat is digital and that handles legal problems pertaining to creative economy.
\end{abstract}

Keywords: Bankruptcy, confiscation by investigating office, Curator's Authority

\section{INTRODUCTION}

A curator has full authority to manage and/or settle bankruptcy assets and estate since the owner of those assts is pronounced bankrupt by the court, even though that court decision might be taken to higher court for appeal. Article 69 UUK-PKPU (Law of Bankruptcy-Suspension of Debt Payment Obligation) stipulates that a curator's job is to manage and/or settle bankruptcy assets. Bankruptcy assets and estate that the curator curates will be used to settle the debts that the bankrupt debtor owes his or her creditors (Novitasari \& Wijayanta, 2016).

In the field, however, curators often face many obstacles that hinder them from doing their job. Hence, curators are required to show integrity in their work, based on the truth and justice and in line with the professional and ethics standards as well as the principles of bankruptcy laws. This is to avoid conflict of interest between the debtor and the creditors. The principles of debtor's obligation towards his or her creditors consist of debt security principle and paripassu principle; which proportionately divide debtor's assets to concurrent creditors with consideration to the amount owed to each creditor or based on corcurus creditorium principle in which the creditors act together as a whole (Situmorang \& Soekarso, 2009). 
Therefore, a bankruptcy institution is an institution that provides solution for all parties involved in the case that the debtor is in a non-payment condition (Hartono, 2018). Bankruptcy is settled with consideration of several principles, i.e. fairness, business sustainability, justice, and integrity. The process of bankruptcy settlement aims to: (a) avoid confiscation and execution by individual creditors and (b) ensure that it only involves the debtor's assets, not his or her person. That way, the debtor will still be capable of performing legal activities (Anisah, 2009).

Confiscation is essentially an act of taking over an individual's or group of individuals' assets under legal order of the law. In civil law, there is a general confiscation, which is stipulated in bankruptcy law. Under the law, both voluntary petition for self-bankruptcy and involuntary petition for bankruptcy; in which the court assigns a bankrupt status to the debtor when it is proven that the debtor can no longer pay his or her overdue and billable debts, become possible (Simanjuntak, 2010).

The regulations in Indonesia's bankruptcy Law is actually an expansion of article 1131 and article 1132 KUH Perdata Indonesian Civil Code, (Muljadi in (Pangestu, 2019)). Bankruptcy is a commercial means to get out of debts, in which case the debtor has lost all capability to pay his or her debts to the creditors (Djohansah, 2011). General confiscation in bankruptcy cases often conflicts with criminal confiscation. An example of this is the case of KSP Pandawa Group Mandiri's Curators Team versus Attorney General of Indonesia Office cq. Depok Office of Attorney General of Indonesia in the Central Jakarta Lain/2018/PN.Jkt.Pst concerning 19 (nineteen) bankruptcy assets after the Central Jakarta Commercial Court has pronounced that KSP Pandawa Group is bankrupt. Those assets are put under general confiscation. However, those assets are then confiscated by Depok Office of Attorney General as evidence in a criminal case.

Another case that shows the conflict between criminal confiscation and general confiscation in bankruptcy is the case of PT. Sinar Central Rejeki's (PT SCR) curators versus the Head of Indonesian Police Force qq. Criminal Investigation Agency (Bareskrim) qq. 2nd Director of Economic and Special Affairs, Criminal Investigation Agency (Bareskrim) of Indonesia's Police Force. PT SCR's curators filed a suit against Bareskrim for the latter's confiscation of the debtor's bankruptcy asset, i.e. Serpong Plaza Commercial Building (Ginting, 2018).

Based on this background, the following research problems are formulated: 1) What are curators' authority and responsibility to sell confiscated bankruptcy assets in the case of criminal confiscation by investigating officers?. 2) What are the legal consequences, in terms of curators' authority and responsibility, in the case that bankruptcy assets are confiscated by the police?. 3) How can the concepts of bankruptcy settlement, as curators' authority and responsibility, be administered in the case of criminal confiscation and general confiscation happen at the same time?

\section{METHOD}

This research employs a juridical normative method and the necessary legal material are collected through literature study. The legal material are analyzed in juridical qualitative approach and statue approach, then presented with descriptive analysis.

\section{III.RESULT AND DISCUSSION}

\section{Curator's Authority and Responsibility}

Curators' authority and responsibility to sell bankruptcy assets include: doing inventory and performing verification of bankrupt debtor's obligations, and doing inventory and investigation of bankrupt debtor's assets, including his or her unpaid bills. The next stage in curators' responsibility is settlement, in which the curators distribute the assets to creditors. The most fundamental job of curators, as stipulated in Article 69 of Law No. 37 Year 2004, is to manage and settle bankruptcy assets.

In the case of KSP Pandawa Group Mandiri vs Attorney General of Indonesia, there is a problem of unclear status of the criminal confiscation in regards to general confiscation of KSP Pandawa Group Mandiri's bankruptcy assets. 19 (nineteen) assets were put into bankruptcy assets after the Central Jakarta Commercial Court pronounced KSP Pandawa Group Mandiri bankrupt. Those nineteen assets had been confiscated by Depok Office of General Attorney as evidence in a criminal case. The main problem in this case is that KSP Pandawa Group Mandiri had been pronounced bankrupt with all its 
legal consequences. However, when the curators performed general confiscation of the bankruptcy assets, 19 (nineteen) assets were found to be under criminal confiscation by the Depok Office of General Attorney. The General Attorney office stated that general confiscation could not be affected on assets with criminal confiscation status.

Criminal law views confiscation as a legal coercion (dwang middelen) performed by authorized officers, i.e. investigating officers, under the order of the Head of State Court. Confiscation is considered legal coercion in criminal law because it is closely related to forcefully taking an individual's right, which is conducted under due process of law based on the criminal laws stipulated in Kitab UndangUndang Hukum Acara Pidana (Indonesian Law of Criminal Procedure/KUHAP).

In principle, a criminal confiscation can be enforced on assets suspected of being used in a criminal activity or being a result of a criminal activity. The context of criminal law emphasizes that confiscation is a fundamental element in the process of proving a crime, in which the confiscated assets will be used as evidence in the investigation process, lawsuit process, and/or trial process in the court. This is different from confiscation in civil law and bankruptcy law contexts. Confiscation in civil law aims to ensure that the lawsuit is not illusoir (misleading). Confiscation will ensure that the defendant will not move the assets or estate, will not be burdened by rents, or will not mortgage the asset to a third party.

Curators' authority and responsibility to sell bankruptcy assets after a criminal confiscation is enforced by investigating officers can still be conducted, as it is protected by Article 31 point (2) of Bankruptcy Law, which governs confiscation in both civil and criminal grounds. In terms of its conflict with Article 39 point (2) KUHAP (Criminal Law), general confiscation has higher status than criminal confiscation. The exception is in the case that the general attorney can prove beyond doubt that the confiscated assets were obtained illegally or through criminal activities. In such a case, in the name of law, criminal confiscation is prioritized.

Protection of creditors' interest in bankruptcy assets that are under criminal confiscation does not nullify the criminal confiscation. It is because criminal confiscation serves to prove a crime. Confiscated assets in this case serve as necessary evidence to prove that a crime has been performed. In the case that KSP Pandawa Group Mandiri is proven to be guilty of a crime, the confiscated assets will likely to be confiscated for the state, or confiscated to be destroyed. However, if the crime is not proven, the bankruptcy assets will be returned to the rightful hand, in this case the curator, to be used in settling debtor's debt to the creditors.

In regards with curators' authority to sell KSP Pandawa Group Mandiri's bankruptcy assets, there should be a party who can mediate the curator with the judge if the criminally confiscated assets turn out to be bankruptcy assets. In addition, the judge should pay close attention in deciding the ownership status of the confiscated assets in his or her decision. That way, if the assets are decided to be under bankruptcy (general) confiscation, they must be returned to the curators who enforce the general confiscation. More importantly, there should be a practical law that can settle the status of such confiscated assets clearly.

Effective since the date of bankruptcy declaration, all assets of KSP Pandawa Group Mandiri are put under the stipulations of Bankruptcy Law Article 1 point 1, Article 21, Article 24 point (1), Article 69 point (1), and Article 98, which state that KSP Pandawa Group Mandiri's assets are under general confiscation, and that the authority to manage all those assets is transferred from the Bankrupt Debtor to the Team of Curators.

\section{Legal Consequences of Police's Confiscation of Bankruptcy Assets/Estate}

Legal consequences of Police's confiscation of bankruptcy assets are effective since the court decision is issued, on local time. Since the bankruptcy status is announced, the bankrupt debtor has no authority, in the eye of the law, to own and manage his or her assets. Any commitment that the debtor has after the bankruptcy statement cannot be paid from the bankruptcy assets, unless the commitment benefits the bankruptcy assets (Article 52 of Indonesian Bankruptcy Law).

Pertaining to curators' authority and responsibility in the case of conflict between criminal confiscation and general confiscation in bankruptcy, Article 39 point (2) of KUHAP (Indonesian Criminal Law) must be prioritized over Article 31 point (2) Law No. 37 Year 2004. This refers to the 
principle that the interest of public (criminal) law must be prioritized over private (civil) law.

A case that shows the conflict between criminal confiscation and general confiscation in bankruptcy is the case of PT. Sinar Central Rejeki's (PT SCR) curators versus the Head of Indonesian Police Force qq. Criminal Investigation Agency (Bareskrim) qq. $2^{\text {nd }}$ Director of Economic and Special Affairs, Criminal Investigation Agency (Bareskrim) of Indonesia's Police Force. PT SCR's curators filed a suit against Bareskrim for the latter's confiscation of the debtor's bankruptcy asset, i.e. Serpong Plaza Commercial Building.

The decision of Central Jakarta Commercial Court Nomor 26/Pailit//009/PN.Niaga.Jkt.Pst. stated that PT SCR was pronounced bankrupt with all its legal consequences. The decision was announced through daily newspapers Kompas and Suara Pembaruan, and was registered to Indonesian Office of News. However, Bareskrim (Indonesian Criminal Investigation Agency) confiscated PT SCR's bankruptcy assets under the confiscation order from the Head of Tangerang State Court as evidence in criminal case No. Pol.BP/384/III/2009/Dit.II.Eksus against Robert Tantular, the former Commissioner of PT SCR.

Criminal confiscation over assets that have been confiscated in civil case, including bankruptcy assets, must seriously consider the relevance and urgency factors as stipulated by Article 39. Article 39 states that there are two indicators to enforce criminal confiscation on assets under general confiscation; i.e. its relevance and urgency.

\section{Bankruptcy Settlement by Curators}

In the case of KSP Pandawa Group Mandiri's Team of Curators, the Court Decision No. 428/ Pid.Sus/2017/PN.Dpk and Court Decision No. 429/Pid.Sus/2017/PN.Dpk stated that the panel of judges granted the demand of the General Attorney that Nuryanto's assets be put into the State's treasury. KSP Pandawa Group's Team of Curators then took legal actions against the decisions, suing that the Jakarta Commercial Court's Panel of Judges return the evidence referred to in Depok State Court's Decision to the curators for settling the debtor's (KSP Pandawa Group) bankruptcy assets. It was because all the debtor's assets were no longer under his or her control since the Central Jakarta Commercial Court's Decision had stated that KSP Pandawa Group was bankrupt. The authority over those assets had been transferred to the curators.

General confiscation has a higher status than other types of confiscation, unless it is stated differently by the law. If any law stipulates that another type of confiscation can be put over general confiscation, the former will have higher status than the latter. An asset under general confiscation can only be subjected to other confiscation under another law (in this case KUHAP/Criminal Law) and based on the public interest, in which the confiscated assets will be used as evidence in a criminal case. Once the confiscated asset is under criminal confiscation, curators must postpone the execution over that asset until its status has been decided by the judge/court.

A case that shows the conflict between criminal confiscation and general confiscation in bankruptcy is the case of PT. Sinar Central Rejeki's (PT SCR) curators versus the Head of Indonesian Police Force qq. Criminal Investigation Agency (Bareskrim) qq. $2^{\text {nd }}$ Director of Economic and Special Affairs, Criminal Investigation Agency (Bareskrim) of Indonesia's Police Force. PT SCR's curators filed a suit against Bareskrim for the latter's confiscation of the debtor's bankruptcy asset, i.e. Serpong Plaza Commercial Building. The bankruptcy asset was confiscated as evidence in a criminal case. The judge, in deciding the status of the confiscated assets, must seriously consider all aspects before making decision concerning the ownership of those confiscated assets. There should be a procedural law that can strictly settle the status of assets in such confiscation. Alternatively, the judge must make a legal breakthrough. Any court decision concerning bankruptcy assets must be based on the legal right over those assets.

\section{IV.CONCLUSION}

Firstly, Curators' authority and responsibility to sell bankruptcy assets after a criminal confiscation is enforced by investigating officers can still be conducted, even though that court decision might be taken to higher court for appeal. Secondly, The legal consequences of police's confiscation of bankruptcy assets, in regards to curators' authority and responsibility, state that in the case of conflict between criminal confiscation and general confiscation. Thirdly, Bankruptcy settlement, as part curators' 
General Confiscation Versus Criminal Confiscation in Regard to Curators' Authority and Responsibility in Bankruptcy Settlement Process

authority and responsibility, can be done in the case that a general confiscation occurs at the same time with criminal confiscation by the investigating officers.

\section{REFERENCES}

Anisah, S. (2009). Perlindungan kepentingan kreditor dan debitor dalam hukum kepailitan di Indonesia. Universitas Indonesia. Retrieved from http://lib.ui.ac.id/detail?id=20449305\&lokasi=lokal

Djohansah, J. (2011). Penyelesaian Utang melalui Kebangkrutan atau Penangguhan Kewajiban Pembayaran Utang. Bandung: Alumni.

Ginting, J. (2018). Criminal Confiscation vs General Confiscation of Bankruptcy A ssets. Jakarta.

Hartono, S. R. (2018). Hukum Perdata Sebagai Dasar Hukum Kepailitan Modern. Jurnal Hukum Bisnis, 6(6). Retrieved from http://garuda.ristekbrin.go.id/documents/detail/1684053

Indonesian Law of Criminal Procedure/KUHAP Kitab Undang-Undang Hukum Acara Pidana/ KUHAP).

Indonesian Bankruptcy Law (Law No. 37 Year 2004).

Novitasari, \& Wijayanta, T. (2016). Perlindungan Hukum Terhadap Independensi Kurator dalam Mengurus dan Membereskan Harta Pailit. Lambung Mangkurat Law Journal, 1(2), 192-204. Retrieved from https:// doi.org/10.32801/lamlaj.v1i2.19

Pangestu, P. D. (2019). Actio Pauliana as the Rights Protection Efforts for Creditors in the Bankruptcy Case. Journal of Private and Commercial Law, 3(1), 26-29. Retrieved from https://journal.unnes.ac.id/nju/ index.php/jpcl/article/view/18673

Simanjuntak, R. (2010). Hukum Kebangkrutan dan Perkembangannya. Jakarta: Law Analysis Center.

Situmorang, V., \& Soekarso, H. (2009). Introduction to Indonesia's Bankruptcy Law. Jakarta: Rineka Cipta. 